\title{
Nature-Based Tourism Sustainability and Climatic Change Implication in Ikogosi Warm Spring Environs, Southwestern Nigeria
}

\author{
Opeyemi A*, Olabiyi C and Raphael 0 \\ Obafemi Awolowo University, Nigeria
}

*Corresponding author: Opeyemi Aniramu, 21 Road 2nd Avenue Gowon Estate Alimosho Lagos, Nigeria, Tel: 2348060650995; Email: samuelaniramu@gmail.com

\section{Research Article}

Volume 3 Issue 2

Received Date: April 19, 2019

Published Date: May 08, 2019

DOI: $10.23880 /$ jenr-16000163

\begin{abstract}
The implications of climatic changes have devastating effects on biodiversity condition particularly nature-based tourism. In this study, spatio-temporal and vegetation changes in the study area were carried out. Climatic data from Nigeria Meteorological Agency (NIMET) for a period of 1975-2014 were analyzed. A 30 meter Landsat image of TM 1991, ETH+ 2002 and OLI 2015 were digitally processed using Arcgis10.3 and Fragstat 3.0. The result showed that rainfall and temperature pattern experience an upward trend with maximum rainfall observed in year $2010(1692.500 \mathrm{~mm})$ and temperature $\left(27.046^{\circ} \mathrm{C}\right)$. Furthermore, results showed that human activities resulted in $25.93 \%$ increase in built-up between the periods of 1991 and 2015 with a substantial loss (29.97\%) of dense vegetation within the study area. In addition, Shannon Diversity Index (SHIDI) showed species diversity decrease of 0.54, 0.47 and 0.21 for year 1991, 2002 and 2015 respectively; NDVI analysis revealed a degraded vegetation with the epoch of the years assessed. The result revealed that changes in rainfall and temperature pattern negatively affected the luxuriant vegetation; uncultured human activities led to massive reduction in the quality of vegetation. The study concluded that climate change and vegetation removal has significant effect on the nature-based tourism and biodiversity conservation.
\end{abstract}

Keywords: Climate Change; Biodiversity; Tourism Development

\section{Introduction}

Climate change is one of the greatest challenges facing the environment today [1]. Coombers, et al. (2008) [2] opined that change in climate will significantly affect nature-based tourism especially biodiversity in-around a tourist zone. Undoubtedly, climate change has acknowledged as an outstanding challenge militating against the vegetation distribution of a naturally endowed location [3]. Therefore, tourism sustainability: according to Gómez and Martin suggested an holistic approach to solving future tourism challenges; and possibility of enjoyable fascinating vegetation cover with eye-catching terrain [4]. 
Nature-based tourism has been considered the most appealing form of land use and biodiversity conservation in Nigeria [5]. Tourism stakeholder often considered potential tourists centre with natural resort facilities; placing premium on the potential threat from climate change which may lower the aesthetic values of the resort centre [3]. Temesgen, et al. [6] reported that environmental factors are key components which determine tourist's choice of holiday destination. Regrettably, there are convincing evidence to show that the world's climate have been changing owing majorly to anthropogenic influences [7,1]. Zoellick RB \& Funk C, et al. affirmed that future variations in rainfall, temperature and other climatic elements poised a serious threat on tourism destination [7,8]. Realistically, nature-based tourism may become unattainable in the future due to a combination of population growth and anthropogenicinduced climate change if unchecked. By implication, negative tourism impacts as a result of climate change can be tackled through mitigation and adaption programs. Furthermore, climate change mitigation programs designed to help tourism business and lower ecological footprints through travel philanthropy programs, funds raising and meeting sustainability criteria in a more ecofriendly way should be upheld [9].
This study aims at investigating the implications of climate change on nature-base tourism. This is with the view of highlighting the impact of climatic variation and sustainability of tourism potentials in the study area. The study focused on the climate change impacts on vegetation cover and fascinating terrain which are tourism resources in Ikogosi Warm Springs Resort Center, southwestern Nigeria. Also, the study assessed the anthropogenic activities within the forested zones of the study area. More specifically, the study was designed to assess the changes in climatic characteristics between the periods of forty years (1975-2014); estimate the spatiotemporal changes between epoch of year 1991 and 2015. The study estimated the Net Diversity Vegetation Index (NDVI); indicating the greenness of the vegetation cover in response to climatic changes as observed in the study area.

\section{The Geographical Position of Ikogosi Warm Spring Centre}

Ikogosi Ekiti is in Ekiti State, South Western, and Nigeria (as shown in Figure 1). It lies between Latitude $7^{\circ} 34^{\prime} \mathrm{N}$ and $7^{\circ} 35^{\prime} \mathrm{N}$, Longitude $4^{\circ} 58^{\prime} \mathrm{E}$ and $4^{\circ} 59^{\prime} \mathrm{E}$ and the elevation of Ikogosi ranges from $457.0-487.5 \mathrm{~m}$ above sea level [5].

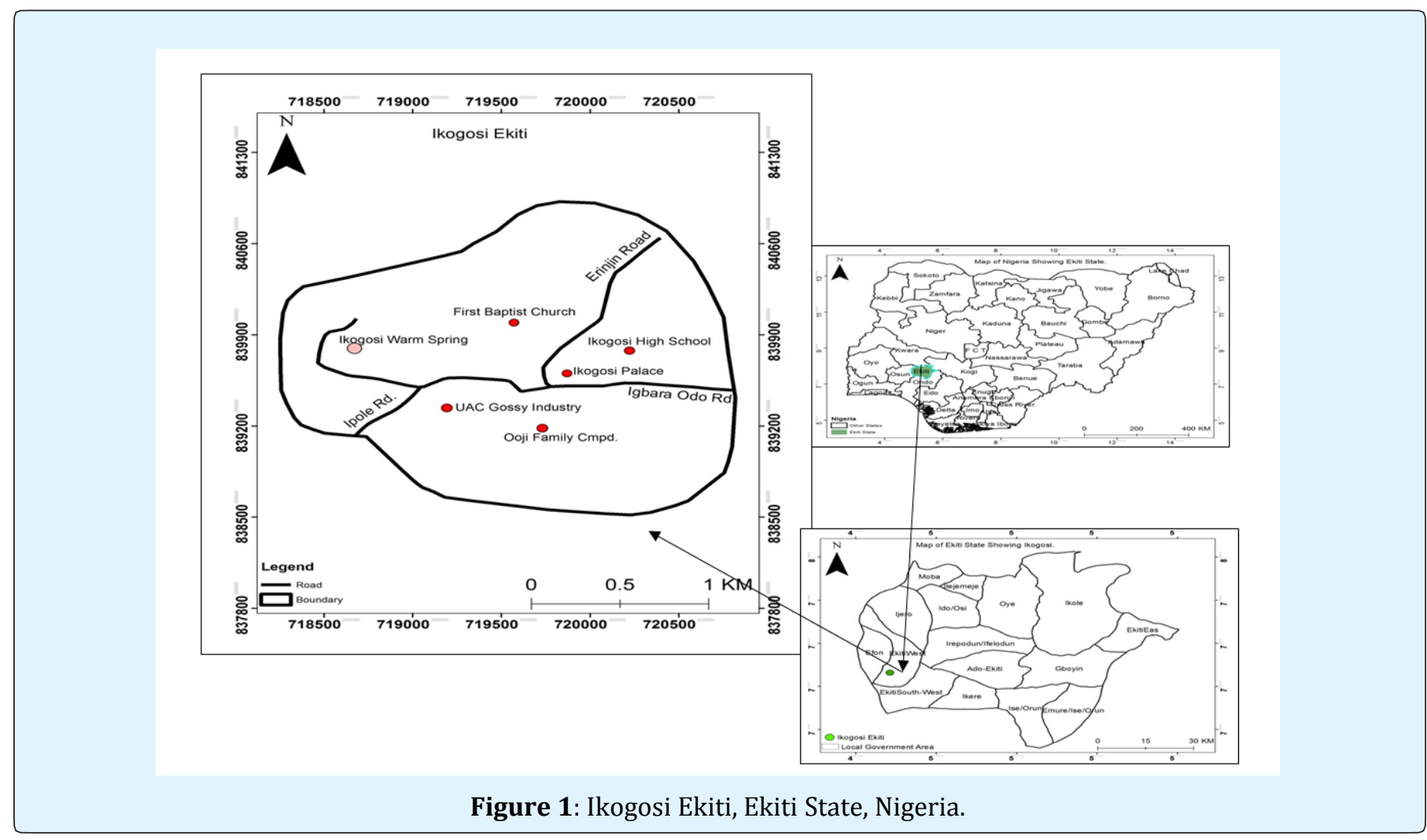


It is located in the tropical rainforest and is characterized by a nearly uniform temperature throughout the year with an annual mean temperature ranging between $21^{\circ} \mathrm{C}$ and $28^{\circ} \mathrm{C}$ with high humidity $[10,11]$. By lithology, Ikogosi Ekiti is located within the Ipole-Iloro and Efon Alaaye schist belt [10]. It is underlain by metamorphic rocks of the basement complex, which outcrops over many parts. Basement complex rocks found here is schist, associated with quartzite ridges [12]. The undulating topography of the entire tourist centre and the symmetry of the surrounding hills add more to the aesthetic beauty of this centre. There is a pass that cuts across the Tourist centre to the equally popular Erinta Water Falls at Ipole Iloro, a few kilometres to the Warm Spring at Ikogosi. The Warm and Cold Springs is situated in a valley surrounded by hills which attract visitors to the tourist center for leisure, vacation, conference and educational research. The natural vegetation of the area is characterized by emergent forest with canopy layers and vines around the undulating terrain of the rocky region in Ikogosi. Also, Ikogosi Ekiti is a rural center with linear settlement, homogeneity in nature and total population of 3,594 (National Population Commission, 2006) [13]. Local populace engaged in primary occupation like farming, fishing, crafting, among others. Numerous tourists visit the place to enjoy the luxurious warm and cold swimming pool provided for recreational needs. Ikogosi is also the home of the 5-star chalets rooms and Gossy Water Bottling Industry, a subsidiary of United Africa Company, Nigeria. This has transformed Ikogosi to a renowned world class tourist centre with average visitor annually reported to be over a million. This great geometric increment in the number of tourists' visit to the Ikogosi Community has necessitated the need to assess the vegetation composition, aesthetic terrain and forest luxuriant as received by tourists during their visit to the study area.

\section{Materials and Methods}

\section{Data Sources}

Multi-dated satellite imageries of Ikogosi were acquired from Global Land Cover Facility (GLCF) on Earth Science Data Interface (http://glcf.umaiacs.umd.edu). The 30 meter Landsat images of Thematic Mapper (TM), Enhanced Thematic (ETM+) and Operational Land Imager (OLI) of 1991, 2002 and 2015 (both path / row 190 / $055)$; covering the study area was acquired. The images were geometrically corrected to Universal Transverse Mercator (UTM) coordinate system. Also, the groundtruth information required for the classification and accuracy assessment of the Landsat images was collected through a field survey which was carried out between December, 2015 and March, 2015 using Global Positioning System (GPS). In addition, Secondary data were employed to meet the objectives of this study. Station observations of rainfall and temperature from 1975 to 2014 were obtained from the Nigerian Meteorological Agency (NIMET) Ado Ekiti, Ekiti State. The climatic data were then processed to obtain monthly, annual and decadal means over the study area. Noticeable changes in the trends and characteristics of the local climate were also estimated and presented.

\section{Satellite Imagery Analysis}

The satellite images were digitally processed using ArcGis 10.3 software and exported to Idrisi Selva 17.0 for supervised classification using Maximum Livelihood. At first, images were geo-rectified to Universal Transverse Mercator (UTM) coordinate system WGS-84 before resampling and enhancement. Training sites corresponding to each classification item (land use class) were chosen; Five land cover and land-use types were defined for supervised classification: built-up area, rock outcrop, dense vegetation, light vegetation and water body; this was done to identify the existing land-use features in the study area. Furthermore, Normalized Difference Vegetation Index (NDVI) analysis was carried out on Landsat data to provide continuous estimation to the amount of greenness of the vegetation cover for the study area. NVDI analysis was performed by difference of sum for the reflectance values of NIR (Landsat band 4 and red 3) for TM 1991 and ETM+ 2002; and (Landsat band 5 and red 4) for OLI 2015. In addition, species diversity were analysed using Shannon's Diversity Index (SHIDI) and Simpson's Diversity Index (SIDI). The study made a projection based on the existing classified imageries changes in Ikogosi landscape composition and configuration among the classified imageries (Figure 2).

However, magnitude of the vegetation greenness was represented in percentage and this was categorized into four types: Highly Degraded ( $>60 \%$ ), Degraded (40-60\%), Moderately Degraded (20-40\%) and Not Degraded $(<20 \%)$.

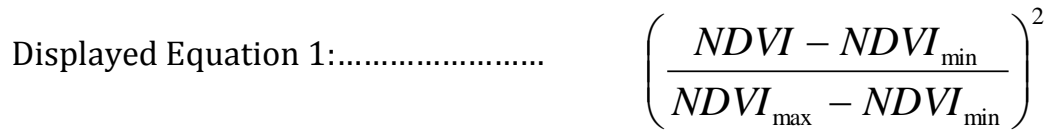




\section{Journal of Ecology \& Natural Resources}

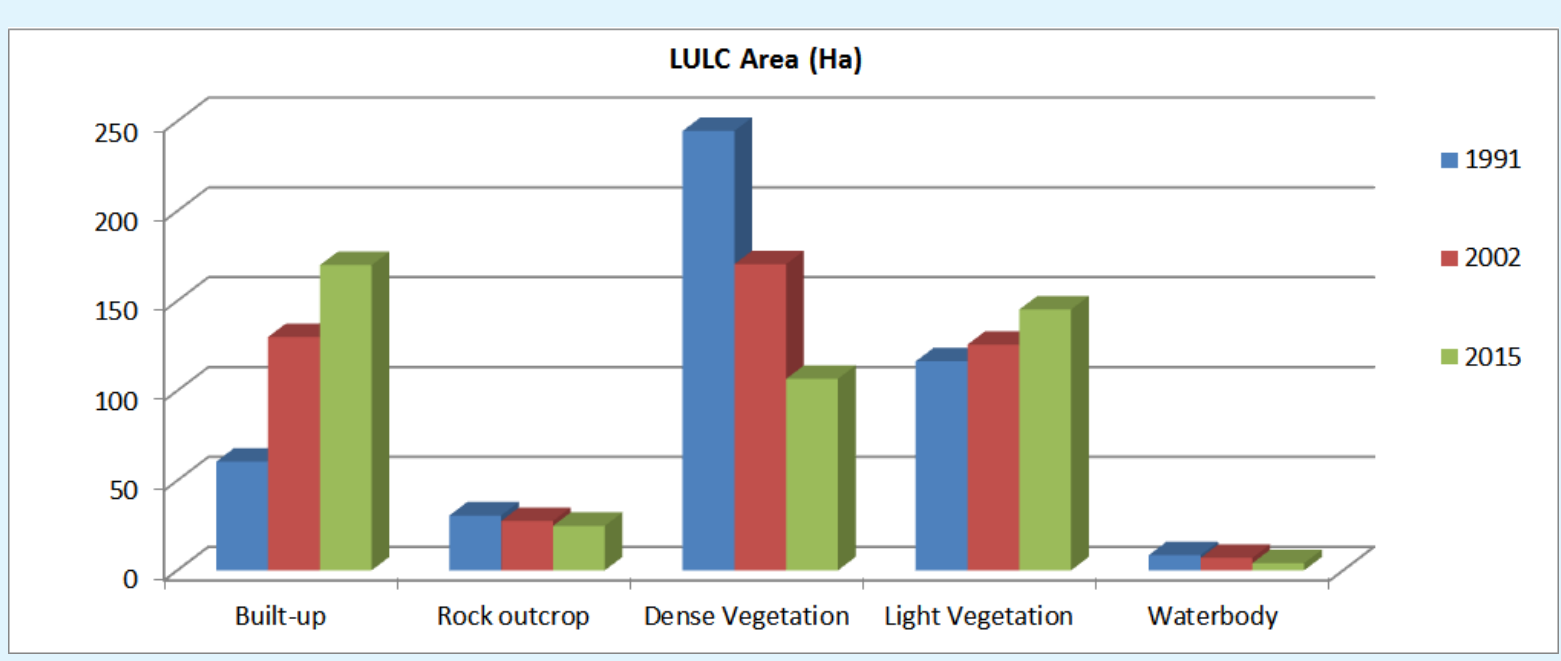

Figure 2: LULC Graph of for Landsat imageries of TM 1991, ETH+2002 and OLI 2015.

\section{Climatic Data Analysis}

Major climatic parameters of consideration for the study were rainfall and temperature for the period forty years (1975-2014). The study understood the nature of rainfall and temperature variations, as well as its trend over time. Statistical examination were done based on estimating for the value of a variable Y (i.e. rainfall or temperature), corresponding to a given value of variable $\mathrm{X}$ (i.e. time); hence, Analysis of Variance (ANOVA) was applied. On completion of data entry, in-depth analysis was carried on the climatic parameters using Microsoft Excel.

\section{Results and Discussion}

\section{Observed Changes in Rainfall and Temperature Pattern}

The finding of the rainfall and temperature pattern as observed in the study area was presented in Table 1 . As shown accordingly, monthly mean rainfall varied among the months of the year as well as temperature. The study revealed that volume of rainfall distribution was extraordinary during the rainy season while the temperature distribution was observed to be significant during the dry season of the year. The rainfall and temperature pattern between the year 1975 to 2014 experienced an upward trend with maximum rainfall observed in year $2010(1692.500 \mathrm{~mm})$ and temperature distribution reached its peak in year $2010\left(27.046^{\circ} \mathrm{C}\right)$. The results of the climatic parameters revealed some upward and download fluctuation across the period of years considered; notwithstanding, analysis of rainfall and temperature data established that climatic phenomena have been highly varied and this has impacted the vegetation condition and luxuriant in the study area. This made, European Environment Agency (2012) [14] to perceive that observed changes in climatic characteristics have implication on nature-based tourism and vegetal condition in connection with unsustainable human activities such as bush burning, deforestation and lumbering. Similarly, Thakadu, et al. reported that vegetation often withered as a result of high rate of temperature with short drought especially during dry season. The resultant economic consequence of climate change on nature-based tourism business was estimated to be loss of aesthetic environs and eye-catching terrain at tourism destination and subsequent reduction in number of tourists' visit. It is pertinent to note that climatic scenario has made some tourist destinations less attractive as wildlife habitat become more porous to attack from human especially in an unprotected environment. By implication, Dube and Kwerepe [3] found out that wildlife; an ingredient of nature-based tourism often migrate to a more secured habitat when the initial homes has been seriously bastardize by a poorly conditioned vegetation cover (vegetation-based tourism) orchestrated by harse climatic conditions. 


\section{Journal of Ecology \& Natural Resources}

\begin{tabular}{|c|c|c|c|c|c|c|}
\hline Month & $\mathbf{R}(\mathbf{m i n})$ & $\mathbf{R}(\mathbf{m a x})$ & $\begin{array}{c}\mathbf{R}(\mathbf{m e a n}) \\
(\mathbf{m m})\end{array}$ & $\mathbf{T}(\mathbf{m i n})$ & $\mathbf{T}(\mathbf{m a x})$ & $\mathbf{T}(\mathbf{m e a n})\left({ }^{\mathbf{}} \mathbf{C}\right)$ \\
\hline January & 0.00 & 47.00 & $\mathbf{6 . 9 7}$ & 23.5 & 28.3 & $\mathbf{2 6 . 1}$ \\
\hline February & 0.00 & 92.90 & $\mathbf{2 5 . 9 5}$ & 25.8 & 29.6 & $\mathbf{2 8 . 3}$ \\
\hline March & 1.60 & 169.20 & $\mathbf{6 7 . 5 3}$ & 27.3 & 29.8 & $\mathbf{2 8 . 7}$ \\
\hline April & 0.00 & 248.00 & $\mathbf{1 1 7 . 3 8}$ & 26.2 & 29.3 & $\mathbf{2 7 . 9}$ \\
\hline May & 0.00 & 271.10 & $\mathbf{1 5 2 . 3 5}$ & 25.8 & 27.8 & $\mathbf{2 6 . 8}$ \\
\hline June & 69.20 & 275.30 & $\mathbf{1 7 6 . 2 6}$ & 25.0 & 26.9 & $\mathbf{2 5 . 8}$ \\
\hline July & 0.00 & 329.70 & $\mathbf{1 6 6 . 6 2}$ & 21.7 & 25.8 & $\mathbf{2 4 . 6}$ \\
\hline August & 22.50 & 349.80 & $\mathbf{1 3 7 . 3 9}$ & 23.6 & 25.5 & $\mathbf{2 4 . 4}$ \\
\hline September & 97.40 & 352.40 & $\mathbf{2 1 2 . 6 3}$ & 24.2 & 25.8 & $\mathbf{2 5 . 1}$ \\
\hline October & 73.70 & 393.10 & $\mathbf{2 1 0 . 0 0}$ & 25.0 & 26.6 & $\mathbf{2 5 . 8}$ \\
\hline November & 0.00 & 135.90 & $\mathbf{4 2 . 5 6}$ & 25.2 & 28.1 & $\mathbf{2 6 . 6}$ \\
\hline December & 0.00 & 52.10 & $\mathbf{5 . 3 3}$ & 15.0 & 28.2 & $\mathbf{2 5 . 5}$ \\
\hline Annual & 921.80 & 1692.50 & $\mathbf{1 3 2 0 . 9 7}$ & 25.3 & 27.0 & $\mathbf{2 6 . 3}$ \\
\hline
\end{tabular}

Table 1: Monthly Observed Rainfall (R) and Temperature (T) for the Study.

\section{Spatio-Temporal Changes Observed in the Study Area}

The entire land coverage in the study area was classified into five categories namely: built-up, rock outcrop, dense vegetation, light vegetation and waterbody. Table 2 revealed that dense vegetation accounted for (53.12\%), light vegetation (25.27\%) and built-up (13.14\%) in year 1991. By 2002; built-up increased significantly by $28.22 \%$ as well as light vegetation $27.29 \%$ while dense vegetation decreases to $37.2 \%$ in the study area. Lastly; by year 2015, built-up and light vegetation experienced continued increase with $39.07 \%$ and $31.54 \%$ respectively; rock outcrop decreased by $5.38 \%$ as well as dense vegetation $(23.15 \%)$ in the total area. The changes in the spatial pattern have a corresponding effective (either decrease or increase) on the land cover; implying a continuous conversion of vegetated area to built-up in recent years as revealed by the study. Arvind, et al. [15] highlighted that high rate of human activities and landscape development were response to the quest for residential and commercial construction; connoting a sizeable reduction in the green infrastructure potentials in the study area. Furthermore, anthropogenic activities within the study area made Orimoogunje (2010) [16] reported that peasant farmers engaged in bush burning as a pre-planting operation therefore reducing the biomass condition needed for nature- tourism business in the study area. Similarly, unabated deforestation has been recognized as one of the major force of biodiversity loss as well as threat to robust vegetation distribution [17]. The outcome of this study corroborates with Salami \& Mengistu (2008) [18] which found out that there is linkage in the rate of population growth, land cover conversion and climate change especially the reduction of carbon stock of a given area contributing immensely to climate change syndrome. As Knowles and Theron (2010) justified that variation in climatic characteristics associated with vegetation degradation has unquantifiable impact on the environment.

\begin{tabular}{|c|c|c|}
\hline Years & SHIDI & SIDI \\
\hline 1991 & 0.54 & 0.38 \\
\hline 2002 & 0.47 & 0.29 \\
\hline 2015 & 0.37 & 0.21 \\
\hline
\end{tabular}

Note: SHIDI $=$ Shannon Diversity Index; SIDI $=$ Simpson Diversity Index

Table 2: Species Diversity Observed in the study area.

\section{Species Diversity and Near-Infrared Analysis on Vegetation Greenness}

Tourism vegetation potential was expressed in the measurement of plants diversity, vegetation density, spatial condition and healthiness of biomass. Results revealed by Shannon-Wiener Index (SHIDI) showed a decrease in the species diversity as values were $0.54,0.47$ and 0.37 for the year 1991, 2002 and 2015 respectively. The findings imply a gradual decrease in species diversity and evenness as engineered by incessant disturbance to the ecosystem. Similarly, Simpson Diversity Index (SIDI) showed a decrease in the species diversity as values were 0.38, 0.29 and 0.21 for the year 1991, 2002 and 2015 respectively (Table 2). The vegetation index output varied significant based on number of factors which include the climatic characteristic, land-use factors and anthropogenic activities on vegetation cover of the study 
area [19]. Also, area covered by vegetation indices significantly varied based on epoch of satellite imageries analyzed; negative indices was associated with large change in land cover feature especially in recent years. This study considered the green infrastructure resources needed for tourism activities and this was corresponded with the changes in rainfall and temperature pattern over the years. The NDVI analysis revealed that more land cover changes were observed in the 2002 and 2015 images compared to the 1991 image; this explains a significant drop in the green portion values for the study (Figures 3, 4 and 5).

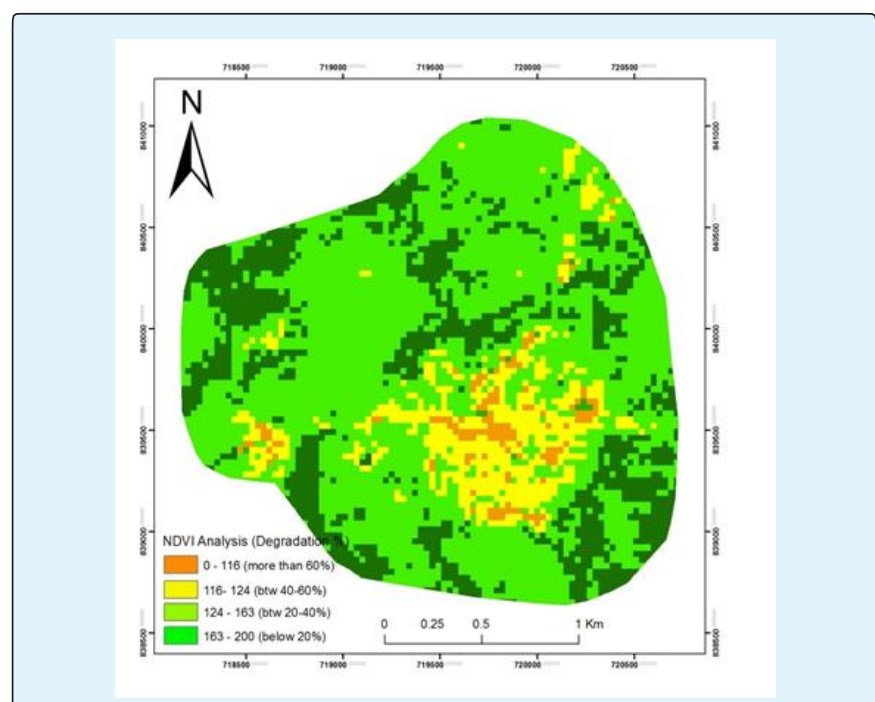

Figure 3: NDVI Analysis in the Ikogosi for 1991.

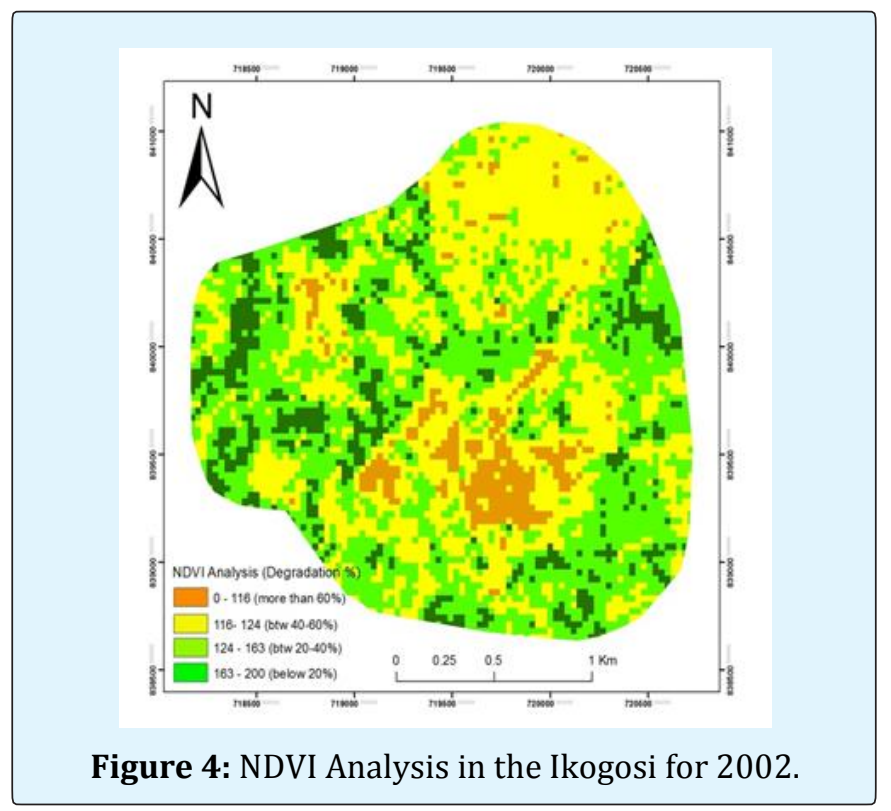

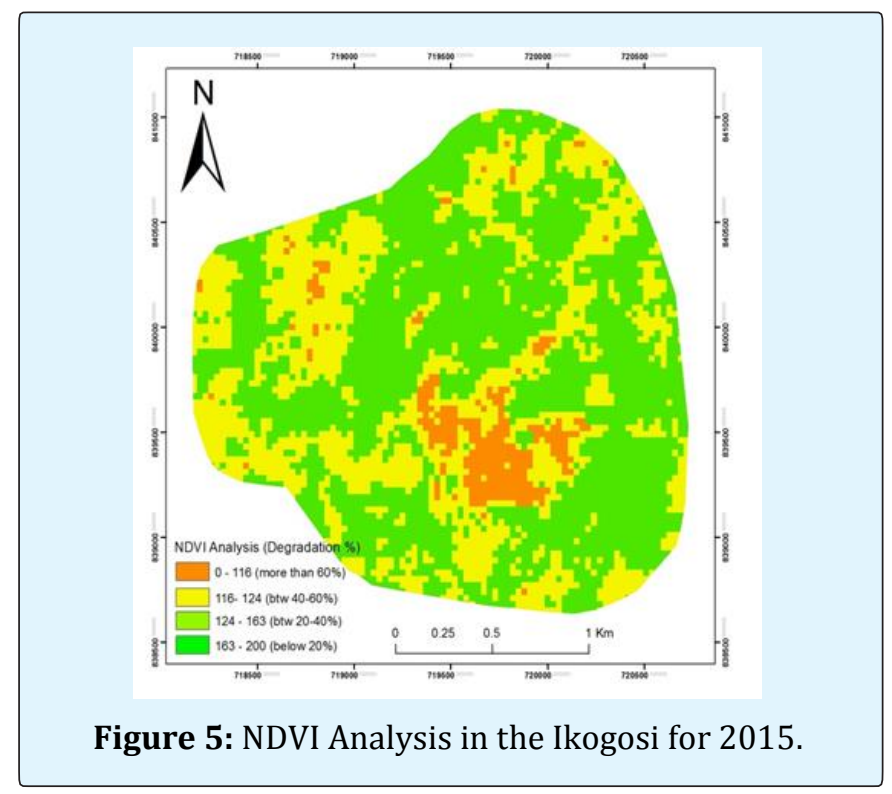

More particularly, green portion in-around the ambient of the Warm Spring Resort Centre have witnessed significant decrease as bulk of the green infrastructures were converted to tourism-supporting facilities; Dantama, et al. [20] stated that this reduction was attributed to the human activities in the study area. In addition, increase in human population and corresponding increase in the settlement pattern has equally contributed to reduction in the green portion in the study area. Considering the rainfall and temperature pattern which were on the increased over the year, it was observed that green space available became greener and luxuriant even though incessant vegetation encroachment was on the increase in the study area [21].

\section{Conclusion and Recommendation}

The study used satellite-based NDVI data and climatic data to establish significant relationship existing between rain-fed vegetation and nature-based tourism potentials. The findings highlighted that changing climatic characteristic and anthropogenic activities has threatened the tourism vegetation sustainability in the study area. Furthermore, findings showed that climate change contributors which came from activities of tourism developmental activities have posed immense implication on the biodiversity conditions of the given resort centre. The magnitude of this effect on the aesthetic terrain and vegetation potentials are more pronounced through land cover modifications in the study area as built-up significantly led to removal of the vegetation. The NDVI analysis revealed that vegetal structure has begun to 


\section{Journal of Ecology \& Natural Resources}

decrease in quality of its greenness and plant diversity; this was attributed to human encroachment in the study area. Specifically, evidence of climate change impact on the green infrastructure was amplified by accumulated human activities which have reduced the flora population density, distribution and greenness in the study area. The unstable pattern of rainfall have threatened the vegetation cover and luxuriant forest that harbor tourism animals; hence, making the resort centre to be endangered. The study concluded that climate change and vegetation removal has significant effect on the green infrastructures, nature-based tourism and biodiversity conservation.

The study recommends the need for tourism sustainability through strict protection of the tourist site against anthropogenic activities. This study provides a basis for future research and urgent action by all stakeholders in Nigeria towards a better understanding of climate change impacts on other elements of the environment hence, finding a way to ameliorate them.

\section{References}

1. Awotoye 00, Mathew OJ (2010) Effects of Temporal Changes in Climate Variables on Crop Production in Tropical Sub-Humid South-Western, Nigeria. African J Environ Sci Tech 4(8): 500-505.

2. Coombers EG, Jones AP, Sutherland W (2008) The Biodiversity Implications of Changes in Coastal Tourism due to Climate Change. J Environ Conserv 35(4): 319-330.

3. Dube OP, Kwerepe RM (2000) Human Induced Change in the Kgalagadi Sands: Beyond the year 2000. In Ringrose D, Chanda R (Eds.), Towards Sustainable Management in the Kalahari Region. Directorate of Research and Development, pp: 244 -258.

4. Li C, Kuang Y, Huang N, Zhang C (2013) The LongTerm Relationship between Population Growth and Vegetation Cover: An Empirical Analysis Based on the Panel Data of 21 Cities in Guangdong Province, China. Int J Environ Res Public Health 10(2): 660-677.

5. Olorunfemi F, Raheem UA (2008) Sustainable Tourism Development in Africa: The Imperative for Tourist/Host Communities Security. J Sustainable Develop Africa 10(3): 201-220.

6. Temesgen M, Hoogmoed WB, Rockstrom J, Savenije HG (2009) Conservation Tillage Implements and
Systems for Smallholder Farmers in Semiarid Ethiopia. Soil Tillage Res 104(1): 185-191.

7. Zoellick RB (2009) A Climate Smart Future, the Nation Newspapers. Vintage Press Limited, Lagos, Nigeria. pp: 18.

8. Funk C, Dettinger MD, Michaelsen JC, Verdin JP, Brown ME, et al. (2008) Warming of the Indian Ocean threatens eastern and southern African food security but could be mitigated by agricultural development. PNAS 105(32): 11081-11086.

9. Knowles T, Theron L (2010) A Literature Review and Overview Report Pertaining to Climate Change Adaptation in Botswana: A Report Submitted to Conservation International Southern Africa Wilderness Program, pp: 457-460.

10. Ojo JS, Olorunfemi MO, Falebita DE (2011) An Appraisal of the Geologic Structure Beneath the Ikogosi Warm Spring in South-Western Nigeria Using Integrated Surface Geophysical Methods. Earth Sci Res J 15(1): 27-34.

11. Hairul NB, Ojo KA, Kasimu MA, Garfar OY, Okoloba V, et al. (2013) Ikogosi Warm Water Resorts: What You Don't Know? Interdisciplinary J Contemporary Res Business 4: 9-15.

12. Ojelabi SI (2012) Assessment of Socio-Economic Impacts of Olumirin Water Fall on Erin Ijesa Community of Osun State, Nigeria. Unpublished PDG Thesis, pp: 49-52.

13. Federal Republic of Nigeria Population Census Commission (2006) Summary and Statistical Report of the 2006 Population and Housing Census, Abuja, pp: 54.

14. European Agency for the Environment (2013) The Environment in Europe: 9th Assessment European Community Official Publication Office, Luxemburg, pp: 66-71.

15. Arvind CP, Nathawat MS (2006) Land Use Land Cover Mapping through Digital Image Processing of Satellite Data-A case study from Panchkula, Ambala and Yamunanagar Districts, Haryana State, India. J Environ Eng Sci 3(2): 512-521.

16. Orimoogunje 00 (2010) Land cover response to changes in forest resources Utilizations in South 


\section{Journal of Ecology \& Natural Resources}

17. Salami AT, Adepoju K (2012) Geo-Information System for Land Degradation Evaluation in Nigeria; In: Bolay JC, Schmid M, Tejada G, Hazboun E (Eds.), Technology and Innovations for Development, pp: 86-122.

18. Salami AT, Mengistu AD (2008) Application of Remote Sensing and GIS in Land Use/Land Cover Mapping and Change Detection in a Part of South Western Nigeria. African J Environ Sci Techn 1(5): 99109.

19. Pickering CM, Hill W (2007) Impacts of Recreation and Tourism on Plant Biodiversity and Vegetation in
Protected Areas in Australia. J Environ Manag 85(4): 791-800.

20. Dantama YU, Abdullahi YZ, Inuwa N (2012) Energy Consumption-Economic Growth Nexus in Nigeria: An Empirical Assessment Based on ARDL Bound Test Approach. European Scient J 8(12): 141-157.

21. Scott D, Jones B, Konopek J (2008) Exploring the impact of climate-induced environmental changes on future visitation to Canada's Rocky Mountain National Parks. Tourism Rev Int 12: 43-56. 